\title{
ЦЕНОВЫЙ ФАКТОР ПРИ ИМПОРТЕ ДЕФИЦИТНЫХ ВИДОВ МИНЕРАЛЬНОГО СЫРЬЯ
}

\author{
Боярко Григорий Юрьевич', \\ gub@tpu.ru \\ Хатьков Виталий Юрьевич², \\ vitaliy@payler.com
Национальный исследовательский Томский политехнический университет, Россия, 635050, г. Томск, пр. Ленина, 30.
2 ПАО «Газпром»,
Россия, 196143, г. Санкт-Петербург, пл. Победы, 2

\begin{abstract}
Актуальность работы обусловлена необходимостью изучения влияния фактора цены на товарные потоки российских импортозависимых минеральных продуктов.

Цель работы: изучение изменений мировых цен на импортозависимые минеральные продукты; определение видов имортозависимого минерального сырья, объемы и доли импорта которых зависят от ценового фактора.

Методы: статистический, графический, логический.

Результаты. За период 1996-2016 гг. выросли мировые цены на следующие импортозависимые минеральные продукты: цинковый концентрат, барит, графит, олово рафинированное, хлорид натрия (каменная соль), бентонит, сода, цирконовый концентрат, глинозем, плавиковый шпат, хромовый концентрат, полевой шпат, диоксид титана (титановый пигмент), бокситы, каолин и огнеупорные глины. Мировые цены снизились на рутиловый концентрат и борную кислоту. Выгодность импортных поставок товарных минеральных продуктов с ценами ниже мировых очевидна, но только при условии стабильности их поставок. Но при этом вероятно быстрое прекращение импортных поставок. Определенную тревогу вызывает группа полной импортозависимости с ценами ниже мировых - марганцевые руды, марганец металлический, плавиковый шпат и феррониобий, поставки которых могут быть прекращены по неэкономическим (политическим) причинам. Необходимо создание национальных добывающих производств, хотя бы частично закрывающих дефицит этих товаров. Ценовый фактор действует, стимулируя при высоких мировых ценах снижение объемов импорта бокситов, бентонита, соды и молибденового концентрата и увеличение импортозависимости при снижении мировых цен для цинкового концентрата и полевого шпата. Выделяется группа товарных видов минерального сырья с импортными ценами на уровне мировых, изменения объемов импорта которых регулируется неценовыми факторами - олово рафинированное, ферровольфрам, бура, силикомарганец, ферромарганец, графит и ферромолибден. $B$ критическую группу с преобладанием неценовых факторов входят также импортозависимые продукты: вольфрамовый концентрат, борная кислота, хлорид натрия (каменная соль), хромовый концентрат, феррохром, диоксид титана (титановый пигмент).
\end{abstract}

\section{Ключевые слова:}

Минеральное сырье, импорт, национальное потребление, ценовый фактор, импортозамещение.

\section{Введение}

Влияние уровня цены на объемы производства являются следствием классического закона спроса и предложения. Особенно они актуальны для тех товаров, востребованность которых высока, а возможности производства ограничены, как например невоспроизводимые природные минеральные товарные продукты [1-7].

В результате образования на постсоветском пространстве новых стран СНГ произошло разрушение экономических связей самодостаточного минерально-сырьевого комплекса и потребляющих отраслей промышленности СССР. Переориентация национальных экономических интересов привела $\kappa$ изменению рынков минерального сырья, в первую очередь для обеспечения собственных нужд, а также к появлению новых направлений поставок сырья в сторону более платежеспособных потребителей дальнего зарубежья [8]. Если в советские времена имелся хронический дефицит только одного вида минерального сырья - высококачественных бокситов, то после перехода в рыночную экономику предприятия Российской Федерации вынуждены импортировать значительные объемы многих стратегических видов минеральных продуктов - алюминиевое и марганцевое сырье, хромовые руды, титановые и цирконовый концентраты, феррониобий, плавиковый шпат и другие [9].

Ценовый фактор иногда играет определяющую роль в формировании товарных потоков дефицитного минерального сырья. Так, например, в 1999 г. потребителем ниобия металлургическим холдингом ОАО «Северсталь» было создано дочернее предприятие ОАО «Стальмаг» по добыче пирохлоровых концентратов на Татарском месторождении в Красноярском крае [10]. В 2000 г. на этом месторождении была пущена обогатительная фабрика мощностью до 90 тыс. т руды в год, достаточных для производства до 1 тыс. т феррониобия. Но после резкого снижения договорных отпускных цен для российских потребителей на бразильский феррониобий компании СBMM с 6700-10000 до 1100-2000 \$/т добыча на Татарском месторождении стала невыгодной и это производство было законсервировано [11].

Импортная зависимость от минерального сырья не является особенностью только россий- 
ского рынка. Ввиду выработки собственных месторождений большинство промышленно развитых стран перешли на импортные поставки сырья. Так, например, Соединенные Штаты Америки были до 70-х гг. XX в. самодостаточными по минеральному сырью и являлись мировыми лидерами экспорта нефти и нефтепродуктов, к настоящему времени импортируют весьма значительные объемы минеральных продуктов, в том числе 47 \% потребляемой нефти. 35 минеральных продуктов внесены в список жизненно-важных для США, из них 32 товарных продуктов относятся к импортозависимым [12].

В аналитических работах по внешнеэкономической деятельности России рассматриваются, как правило, только проблемные импортные потоки товаров, при этом ставится вопрос об их импортозамещении [13-17].

Многие минеральные товарные продукты, востребованные на российских производствах, либо не имеют достаточно надежных источников сырья, либо их производство недостаточно для стабильного и полного обеспечения потребностей (марганцевое и алюминиевое сырье, глинозем, плавиковый шпат). В то же время для отдельных минеральных товаров на территории России имеется достаточное количество известных и подготовленных месторождений (титановое и циркониевое сырье, ниобий и др.), но их освоение не ведется ввиду наличия стабильных импортных товарных потоков. И для первой и, особенно, для второй группы основным фактором регулирования, а зачастую и отсутствия альтернативных вариантов, является уровень цен на них.

\section{Факторы ценобразования}

Ценообразование для минеральных продуктов, как и для всех товаров, определяется соотношением их спроса и предложения. В первую очередь, базовые цены формируются на основе себестоимости их производства. Группа общераспространенных ископаемых обычно представлена дешевыми товарными продуктами местного спроса, перевозить которые даже на небольшое расстояние уже невыгодно (песок, глина, торф и др.). Цены на минеральные продукты группы преимущественно национального спроса (уголь, природный газ, железные руды и др.) определяются, в первую очередь, по состоянию национального рынка их спроса и предложения. В их цене большую долю составляют транспортные расходы, зависящие от транспортной логистики. Зачастую цены на эти минеральные продукты и тарифы на их транспортировку регулируются со стороны правительства стран, но с другой стороны на них уже оказывают влияние соответствующие цены мирового рынка. И последняя группа ценообразования минеральных продуктов с высокой стоимостью и низкой долей транспортных расходов в их себестоимости - нефть, цветные и драгоценные металлы, алмазы и др. Большая часть объемов товаров этой группы уча- ствует в мировой торговле и их ценообразование регулируется ситуацией мирового рынка. Эти товары котируются на международных товарных биржах и на их ценообразование оказывают влияние множество внешних факторов. Большинство минеральных продуктов относятся к товарам низкой ценовой эластичности, поэтому краткосрочные всплески изменений цен (роста и падения) возникают в результате случайных факторов: природных и техногенных катаклизмов, экономических и политических кризисов, сезонных изменений спроса, ажиотажных спекуляций и др. В долгосрочном плане на ценообразование минеральных товарных продуктов действует правило Хотеллинга - неизбежного роста цен ввиду исчерпания ресурсов для отрасли в следствии деградации качества остаточных ресурсов, выработки ближайших к потребителям источников сырья и перехода к менее качественным и более удаленным [18]. Но скорости роста для отдельных видов минеральных товарных продуктов неодинакова ввиду различий особенностей их рынков предложения и сбыта. Так, например, ценообразование феррониобия является следствием монополии его предложения Бразилией (свыше 85 \% мирового рынка), где разрабатывается уникальное ниобиевое месторождение Араша. Аналогично в 70-е гг. ХХ в. в Китае сформировалась отрасль добычи редкоземельных элементов из месторождений ионных глин, что привело к закрытию большинства производств товарных РЗЭ во всем мире, и сформировалась абсолютная монополия предложения китайских индивидуальных редкоземельных металлов. На рынки спроса и, соответственно, на цены на минеральное сырье оказывают влияние и картельные объединения производителей (ОПЕК, нефть), переработчиков (Джонсон Матей, металлы платиновой группы), торговцев (Де Бирс, алмазы, Тиффони, драгоценные камни). В значительно меньшей степени меняются цены на недефицитные общераспространенные полезные ископаемые (песок, глина и др.), но и на них действует правило Хотеллинга, приводя к увеличению цены в длительном периоде времени.

\section{Исходные данные}

Собраны данные по импортозависимым товарным минеральным продуктам, используемым в России - их объемы производства и потребления (Роснедра [19], Госкомстата РФ [20]), импорта и экспорта (Федеральной таможенной службы РФ [21]). В качестве мирового уровня цен на минеральные товарные продукты используются цены импорта в США (по данным Геологической службы США [22]). Период анализа цен - 1996-2016 гг. В исследуемую группу включены все виды минеральных товаров, для которых максимальное значение годовой доли импорта от потребления хотя бы однажды превысило 25 \% от потребления. Эти 30 видов минеральных продуктов приведены в таблице, где рассчитаны ключевые показатели цен и 
уровня импортозависимости. Анализ сравнительных данных осуществлялся на построенных графиках-диаграммах изменений мировых цен во времени относительно средних цен, изменений во времени объемов импорта и импортных цен, изменений во времени доли импорта и импортных цен на импортозависимые минеральные товарные продукты.

таблица. ППказатели ценообразования и обвелов илпорта илпортозависилых минеральных продуктов. Составлено по данныл Роснедра, Госколстата РФ, Федеральной таможенной службы РФ и Геологической службы США [19-22]

Table. $\quad$ Pricing and volumes of import of import-dependent mineral products. Compiled according to Rosnedra, Goskomstat, the Federal customs service of the Russian Federation and the US Geological survey [19-22]

\begin{tabular}{|c|c|c|c|c|c|c|c|c|}
\hline \multirow{2}{*}{$\begin{array}{l}\text { Товарный минеральный продукт } \\
\text { Commercial mineral product }\end{array}$} & \multicolumn{2}{|c|}{$\begin{array}{c}\text { Объемы националь- } \\
\text { ного производства, } \\
\text { тыс. т } \\
\text { Volume of domestic } \\
\text { production, kt }\end{array}$} & \multirow{2}{*}{ 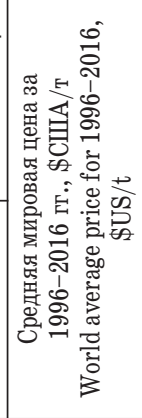 } & \multirow{2}{*}{ 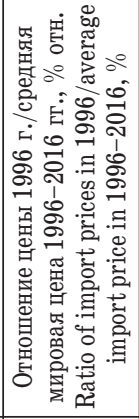 } & \multirow{2}{*}{ 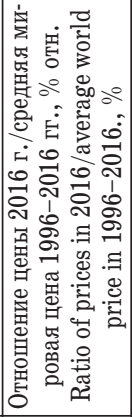 } & \multirow{2}{*}{ 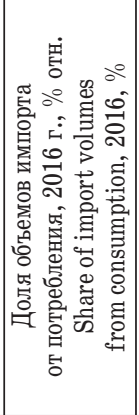 } & \multirow{2}{*}{ 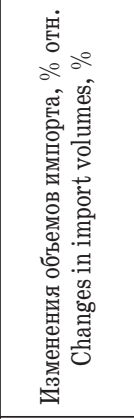 } & \multirow{2}{*}{ 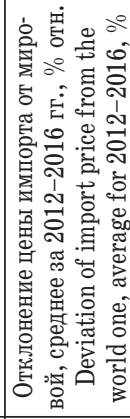 } \\
\hline & 1996 & 2016 & & & & & & \\
\hline Марганцевый концентрат/Manganese ore & 272,9 & 945,4 & 145,8 & 60,8 & 99,5 & 100 & $+4,2$ & $-25,0$ \\
\hline Ферромарганец/Ferromanganese & 130,2 & 33,7 & 914,9 & 60,2 & 82 & 23,5 & $-44,0$ & $+4,4$ \\
\hline Силикомарганец/Silicomanganese & 209,6 & 221,1 & 836,9 & 69,5 & 90,1 & 50,1 & $-34,2$ & $-4,1$ \\
\hline Марганец металлический/Manganese metal & 0 & 42,9 & 2084,8 & 85,0 & 81,2 & 100 & 0 & $-28,0$ \\
\hline Хромовый концентрат/Chrome ore & 360,6 & 804,0 & 184,5 & 58,5 & 108,4 & 64,6 & $-13,0$ & $-35,3$ \\
\hline Феррохром/Ferrochrome & 26,0 & 10,1 & 1165,0 & 101,6 & 106,4 & 17,0 & $-14,0$ & $-20,0$ \\
\hline Бокситы/Bauxites & 1250,0 & 110,2 & 35,8 & 98,6 & 117,0 & 1,9 & $-27,5$ & $+100,0$ \\
\hline Глинозем/Alumina & 3686,0 & 4746,0 & 338,8 & 69,5 & 124,0 & 66,7 & $+2,2$ & $-23,2$ \\
\hline Цинковый концентрат/Zinc ore & 145,8 & 185,9 & 859,8 & 43,3 & 152,5 & 60,2 & $-18,6$ & $-61,0$ \\
\hline Олово рафинированное/Refined tin & 0 & 1,2 & 12525,2 & 49,4 & 131,1 & 100 & $+55,7$ & $-0,7$ \\
\hline Ильменитовый концентрат/Ilmenite concentrate & 63,0 & 230,5 & 124,2 & 88,2 & 84,5 & 100 & $-1,2$ & $+60,8$ \\
\hline Рутиловый концентрат/Rutile concentrate & 14,5 & 7,2 & 739,5 & 105,8 & 98 & 100 & 0 & $+20,9$ \\
\hline Диоксид титана/Titanium dioxide & 50,0 & 57,3 & 2152,0 & 80,7 & 114,5 & 58,9 & $-41,1$ & $-16,7$ \\
\hline Цирконовый концентрат/Zircon concentrate & 6,1 & 6,8 & 828,5 & 48,3 & 110,8 & 100 & 0 & 15,8 \\
\hline Вольфрамовый концентрат/Tungsten ore & 0,01 & 1,1 & 10347,8 & 30,2 & 81,4 & 44,8 & $+81,8$ & $-59,3$ \\
\hline Ферровольфрам/Ferrotungsten & 0,1 & 0,01 & 20894,8 & 30,5 & 80,8 & 10,9 & 0 & $+0,6$ \\
\hline Молибденовый концентрат/Molybdenum ore & 1 & 2,3 & 13196,6 & 39,1 & 59,1 & 24,0 & $-31,6$ & $+50,7$ \\
\hline Ферромолибден/Ferromolibden & 0,6 & 0,08 & 18306,9 & 38,2 & 80,5 & 5,2 & $-59,5$ & $-1,2$ \\
\hline Феррониобий/Ferroniobium & 0,2 & 4,3 & 21824,0 & 69,5 & 91,6 & 100 & 0 & $-10,3$ \\
\hline $\begin{array}{l}\text { Мишметалл (смесь редкоземельных металлов) } \\
\text { Mischmetal (mixture of rare earth metals) }\end{array}$ & Н.д./N.da. & 0,07 & 13,7 & 65,7 & 40,9 & 100 & H.д./N.da. & $-18,3$ \\
\hline Плавиковый шпат/Fluorspar & 238,0 & 177,7 & 265,3 & 52,2 & 105,5 & 100 & $+12,8$ & $-51,4$ \\
\hline Барит/Barite & 19,4 & 49,3 & 89,2 & 59,5 & 168,2 & 11,7 & $+16,6$ & $-59,5$ \\
\hline Бентонит/Бентонит & 146,6 & 85,4 & 52,5 & 68,2 & 141,0 & 20,3 & $-79,7$ & $+100,7$ \\
\hline Каолин/Kaolin & 159,9 & 407,1 & 126,2 & 95,1 & 104,6 & 39,0 & $+42,6$ & $-39,3$ \\
\hline Огнеупорные глины/Ball clay & Н.д./N.da. & 961,0 & 44,4 & 99,1 & 101,4 & 36,7 & $-13,8$ & $+1,4$ \\
\hline Полевой шпат/Feldspar & 2,0 & 612,0 & 58,8 & 74,8 & 117,3 & 44,6 & $+43,9$ & $-32,2$ \\
\hline Графит/Graphite & Н.д./N.da. & 3,2 & 801,4 & 87,2 & 169,7 & 16,9 & $-22,2$ & $-0,3$ \\
\hline Хлористый натрий/ $\mathrm{NaCl}$ (Salt) & 500,0 & 1806,0 & 30,0 & 73,8 & 150 & 37,5 & $+18,2$ & $+26,7$ \\
\hline Сода/Soda & 50,0 & 95,0 & 100,9 & 81,9 & 148,7 & 3,7 & $-19,5$ & $+74,2$ \\
\hline Борная кислота/Boric acid & H.д./N.da. & 15,8 & 526,0 & 114,6 & 90,9 & 67,2 & $+34,4$ & $+16,0$ \\
\hline Бура/Borax & Н.д./N.da. & 29,6 & Н.д. N.da. & $\begin{array}{l}\text { He oпр. } \\
\text { N.de. }\end{array}$ & $\begin{array}{l}\text { He опр. } \\
\text { N.de. }\end{array}$ & 67,3 & $+6,9$ & 0 \\
\hline
\end{tabular}

H.d. - нет данных/N.da. - no data.

Hе опр. - не определено/N.de. - not determined. 


\section{Анализ изменения мировых цен во времени}

На диаграмме рис. 1 показаны позиции отношений мировых цен на минеральные товарные продукты к их средней мировой цене за 1996-2016 гг. Это позволяет выделить группы изменений цен и рейтинги отдельных товарных продуктов.

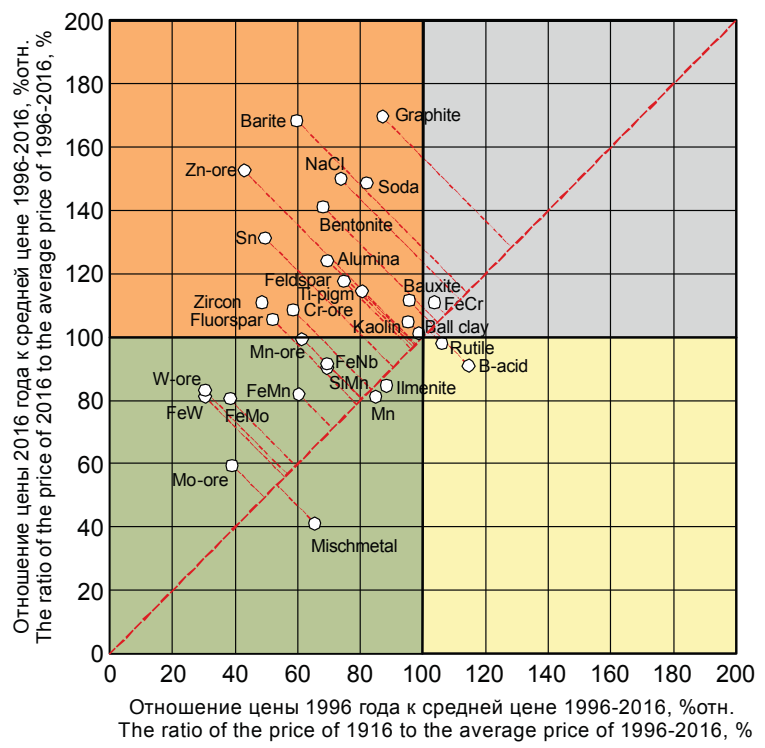

Pис. 1. Соотношение иен илпорта на минеральные товарные продукты и их средней иены за период 1996-2016 г2. Красный сектор - товары абсолютного роста иен, зеле ный - товары с переленныли, относительно низкили це нали; желтый - товары абсолютного падения иен. Диа гональ - линия равновесия иен (среднее за 1996-2016 г2.), длина проекиии цены товаров на нее представляет относительную величину отклонения цены от равновесия. То варные минеральные продукты: барит, бентонит, бокси ты, борная кислота, бура, вольфрамовый кониентрат, глинозем, графит диоксид титана (титановый пиг мент), ильленитовый кониентрат, каолин, марганец металлический, марганиевые руды, мишлеталл (смесь редкоземельных металлов), молибденовый кониентрат, огнеупорные глины, олово рафинированное, плавиковый шпат, полевой шпат, рутиловый концентрат, силико марганеи, сода, ферровольфрам, ферромарганеи, ферромо либден, феррониобий, хлористый натрий (каленная соль), хромовый кониентрат, иинковый концентрат, иирконовый кониентрат

Fig. 1. Ratio of import prices for mineral commodity products and their average price for the period of 1996-2016. Red sectorproducts of absolute price growth, green - products with variable, relatively low prices; yellow - goods of absolute price fall. Diagonal - the price equilibrium line (average for 1996-2016), the length of the products price projection on the equilibrium line represents the relative value of the price deviation from the equilibrium. Commercial mineral products: barite, bentonite, bauxite, boric acid (B-acid), borax, tungsten ore (W-ore), alumina, graphite, titanium dioxide, titanium pigment (Ti-pigm), ilmenite, kaolin, metal manganese (Mn), manganese ore (Mn-ore), mischmetal (mix of rare earth metals), molybdenum ore (Mo-ore), ball clay, refi ned tin (Sn), fluorspar, feldspar, rutile, silicomanganese (SiMn), soda, ferrotungsten (FeW), ferromanganese (FeMn), ferromolybdenum (FeMo), ferroniobium (FeNb), rock salt $(\mathrm{NaCl})$, chrome ore (Cr-ore), zinc ore (Zn-ore), zir con
В левом верхнем (коричневом) секторе (рис. 1) находятся минеральные товарные продукты с растущей иеной, увеличившие свою цену к 2016 г. (выше средней цены 1996-2016 гг.) и относительно низкой цены 1996 г. В порядке уменьшения величины изменений цены выстраивается рейтинг (по длине проекции на диагональную линию средней цены): цинковый концентрат, барит, графит, олово рафинированное, хлорид натрия (каменная соль), бентонит, сода, цирконовый концентрат, глинозем, плавиковый шпат, хромовый концентрат, полевой шпат, диоксид титана (титановый пигмент), бокситы, каолин и огнеупорные глины.

В левом нижнем (светло-желтом) секторе - товары переленных относительно низких иен, уменьшившие свою цену к 2016 г. и относительно низкой цены 1996 г. Это товары, имеющие максимум цены во время расширения спроса при экономическом росте Китая в 2004-2012 гг. или минимум цен в период 1996-2016 гг., цена которых зависит от конъюнктуры рынка. Здесь можно выделить:

1) подгруппу с краевыли иенали 1996 и 2016 г2. выше средней иены (сортировка рейтинга по величине уменьшения отклонения от диагональной линии средних цен) - вольфрамовый концентрат, ферровольфрам, хромовый концентрат, ферромолибден, марганцевый концентрат, феррониобий, ферромарганец, силикомарганец и молибденовый концентрат;

2) подгруппу с краевыли иенали 1996 и 2016 г2. ниже средней цены (сортировка рейтинга по величине увеличения отклонения от диагональной линии средних цен) - ильменитовый концентрат, марганец металлический и мишметалл (смесь редкоземельных металлов).

В правом нижнем (жёлтом) секторе - товары с падающей иеной, понизившие свою стоимость к 2016 г. и с низкой ценой 1996 г. В нем находится только рутиловый концентрат и борная кислота.

Верхний правый сектор высоких цен 1996 и 2016 гг. содержит лишь одну позицию товара феррохрома.

Анализ изленений объелов илпорта и их иены во врелени (рис. 2). Из классических правил спроса и предложения при росте цены на товар будут уменьшаться объемы его продаж и наоборот.

Для импортозависимых товаров на российском рынке это правило соблюдается для двух групп (рейтинг товаров по величине длины проекции на срединную линию):

- при снижении илпортной цены увеличивается объелы и доля илпорта (левый верхний сектор): вольфрамовые руды, каолин, барит, полевой шпат и плавиковый шпат;

- при повышении цены снижаются объелы и доля илпорта (правый нижний сектор): бентонит, сода, ильменитовый концентрат, ферромарганец, огнеупорные глины.

В красном правом верхнем секторе (рис. 2) находится критическая группа товаров, увеличивших объемы импорта при повышении их цен: бор- 
ная кислота, имеющая опережение роста доли и объемов импорта над ростом цен, и хлорид натрия (каменная соль), для которого рост цен опережает рост объемов и доли импорта. Эти товарные продукты весьма критичны:

- борная кислота, производимая ОАО «Бор» в Приморском крае, экспортируется в страны Азии, а потребители в европейской части России импортируют этот продукт преимущественно из Турции; налицо иррациональный встречный импорто-экспортный поток [23];

- увеличивающийся импорт хлорида натрия (каменной соли) с Украины и Белорусии вообще иррационален при наличии достаточных добывающих производств холдинга 000 «Руссоль» (Оренбургская обл.) и ОАО «Тыретьский солерудник» (Иркутская обл.); в 2016 г. хлорид натрия был включен в санкционный список запрета импорта из Украины пищевых продуктов и ситуация с этим товарным продуктом еще более усложнилась.

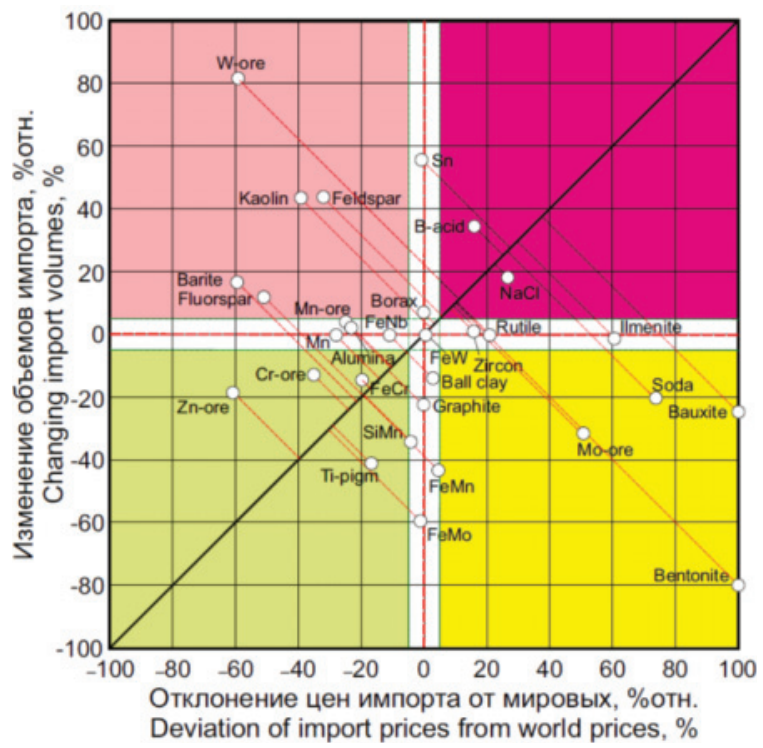

Pис. 2. Соотношение отклонения иен илпорта минеральных то варных продуктов от мировых и величины изменений доли илпорта от потребления во времени. Красные сектора - товары, увеличившие долю илпорта, желтые - уме ньшившие. Бледные левые сектора - товары с иеной, ме ньше мировой, интенсивно окрашенные правые - с иеной больше мировой. Белье сектора - с товарами с неизменной иеной и/или неизленныли объемами илпорта. Товар ные минеральные продукты - сл. на рис. 1

Fig. 2. Ratio of deviation of import prices of mineral commodity products from the world ones and the value of changes in the share of imports from consumption over time. Red sectors - goods that increased the share of imports, yellow - reduced. Pale left sectors - products with the price less than the world one, intensely colored right - with the price higher than the world one. White sectors - products with the same price and/or unchanged volume of import. Commercial mineral products see Fig. 1

В светло-желтом левом нижем секторе - товары, где ценовый фактор регулирования вторичен и имеет место снижение объемов импорта при одно- временном снижении иен этих товаров. Они подразделяются на подгруппы: 1) товаров с опережением падения цен над темпами уменьшения импорта: цинковый концентрат, хромовый концентрат, феррохром, и 2) товаров с опережением уменьшения импорта над падением уровня цен: силикомарганец и диоксид титана (титановый пигмент).

Это вторая критическая группа минеральных товарных продуктов, где ценовый фактор играет второстепенную роль:

- по хромововому кониентрату осуществляются аналогичные устойчивые импортные поставки с Донского ГОКа из Республики Казахстан на российские ферросплавные заводы (до 945 тыс. т/год); - феррохром случайно оказался в составе «импортозависимых» товарных продуктов; ввиду высоких мировых цен этот товарный продукт является экспортоориентированным (до 360 тыс. т/год и до $80 \%$ от производства); поэтому небольшие объемы импорта (до 80 тыс. т/год) являются транспортно-логистическими поставками с ферросплавных заводов Хромтау и Аксу в Республике Казахстан российским потребителям;

- причиной увеличения импорта силиколарганиа является тенденция замещения им более дорогого ферромарганца в производстве чугуна и стали; несмотря на рост национального производства силикомарганца (с 50 до 230 тыс. т/год), его импорт снижается, но незначительно - с 320 тыс. т (92\% от потребления) в 2005 г. до 220 тыс. т $(50 \%)$ в 2016 г.;

- до 2014 г. диоксид титана (титановый пигмент) был полностью импортозависимым товарным продуктом; при переходе производства ОАО «Крымский титан» под российскую юрисдикцию импорт снизился незначительно (до 59 \%) из-за увеличения объемов российского потребления и необходимости исполнений старых экспортных обязательств этого предприятия.

Товарные продукты, входящие в груnпy абсолютного илпорта, располагаются на горизонтальной линии отсутствия изменения объемов импорта - это марганец металлический, марганцевые руды, глинозем, феррониобий, цирконовый, рутиловый и ильменитовый концентраты.

Товарные продукты, не имеющие изменений илпортной цены, располагаются на вертикальной срединной линии: олово рафинированное, графит и ферромолибден.

Не имеет изменений, ни по цене, ни по объемам импорта, только один товар - ферровольфрам.

Совлестный анализ изленений иен товаров и долей илпорта от реализации (рис. 3). Следует определиться по порогам отнесения товарного минерального сырья к импортозависимым. $K$ примеру, в списке стратегически важных минеральных продуктов США градация импорта более дробная и определена с порогами в 15, 50, 70, 85, 90 и $95 \%$ [12]. Было произведено ранжирование 95 изучаемых минеральных продуктов по величине их доли 
импорта от реализации. В $25 \%$-м сегменте высоких значений доли импорта $(\hat{\mathrm{C}}+\delta)$ находятся продукты с долей импорта свыше 24,9\%, а в $12,5 \%$ м сегменте $(\hat{\mathrm{C}}+2 \delta)$ - с долей импорта от реализации свыше $60,2 \%$. Таким образом, можно определить нижний порог импортозависимости в $25 \%$, критичный - в $60 \%$, а полной импортозависимости в $90 \%$.

В самых верхних секторах (90-100 \% доли импорта) находится группа товарных минеральных продуктов с полной илпортозависилостью. Она включает три подгруппы полной илпортозависимости товаров:

- с растущей иеной товаров (рейтинг по уменьшению цены): ильменитовый, рутиловый и цирконовый концентраты;

- с падающей иеной товаров (рейтинг по увеличению цены): плавиковый шпат, марганец и марганцевые руды, феррониобий;

- с малыли изленениел иен товаров: олово рафинированное и ферровольфрам.

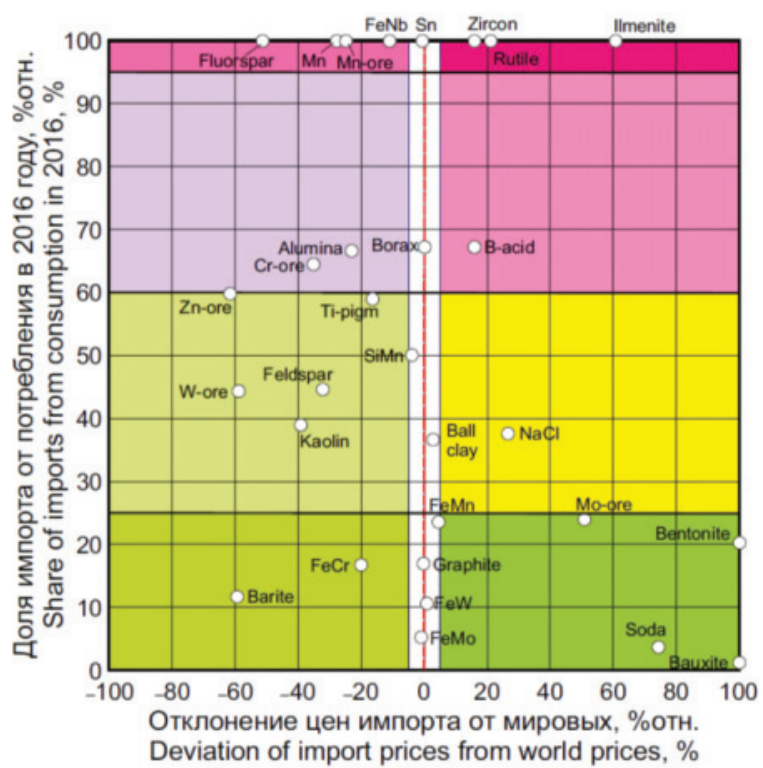

Pис. 3. Соотношение отклонения цен илпорта минеральных то варных продуктов от мировых и доли объемов импорта от потребления. Зеленые сектора - илпортонезависи мые товары (доля импорта $<25 \%$ ), желтые - импортозависилые товары (25-60\%), светлые красные - това ры с высокой илпортозависилостью (60-90\%), интенсивно окрашенные красные сектора - полностью импор тозависимые (>90\%). Товарные минеральные продукmы- см. на рис. 1

Fig. 3. Ratio of deviation of import prices of mineral commodity products from the world ones and the share of imports from consumption. Green sectors - import-independent goods (import share $<25 \%$ ), yellow sectors - import-dependent goods (25-60\%), light red sectors - goods with high import dependence (60-90\%), heavily colored red sectors - fully import dependent (>90\%). Commercial mineral products - see Fig. 1

В следующей группе верхних секторов (60-90\% доли импорта) находится группа товарных минеральных продуктов с высокой илпортозависилостью. Она включает три подгруппы:
- высокой илпортозависилости с растущей иеной: борная кислота;

- высокой илпортозависилости с падающей иеной (рейтинг по уменьшению величины доли импорта и увеличения цены): хромовый концентрат и глинозем;

- высокой илпортозависилости с мальл изменением цен: бура.

В «желтой» группе секторов (25-60\% доли импорта) находится группа товарных минеральных продуктов с улеренной илпортозависилостью. Она включает три подгруппы:

- улеренной илпортозависилости с растущей иеной: хлорид натрия (каменная соль);

- умеренной илпортозависимости с падающей ценой (рейтинг по уменьшению величины доли импорта и увеличения цены): цинковый концентрат, титановый пигмент, вольфрамовые руды, полевой шпат и каолин;

- умеренной илпортозависилости с мальл изменениел иен: силикомарганец и огнеупорные глины.

В нижней («зеленой») группе секторов (доли импорта менее $25 \%$ ) находится группа илпортонезависилых товарных линеральных продуктов. Она включает три подгруппы:

- илпортонезависилье с растущей иеной (рейтинг по уменьшению цены): бокситы, бентонит, сода, молибденовый концентрат и ферромарганец;

- илпортонезависилые с падающей иеной (рейтинг по увеличению цены): барит и феррохром;

- илпортонезависилые с малыл изленениел иен: графит, ферровольфрам и ферромолибден. Именно на основании экономической выгоды при замещении импортных поставок дорожающих минеральных товаров продуктами российского производства произошел переход из категории импортозависимых материалов в импортонезависимые для следующих минеральных продуктов:

- бокситы, импорт которых в 1996-1999 гг. составлял 0,9-1,2 млн т/год на сумму 20-34 млн \$ США/год, к 2001 г. упал до 50 тыс. т/год; кроме ценового фактора собственно стоимости бокситов важную роль в решении по резкому снижению их импорта сыграла мировая тенденция переноса производства глинозема из бокситов в места их добычи или в узловые точки морских портов в пространственной логистической цепочки «бокситовый рудник $\rightarrow$ глиноземный завод $\rightarrow$ алюминиевый завод»;

- бентонит, используемый для производства буровых растворов, до 1999 г. поступавший в Россию только по импорту (120-190 тыс. т/год на сумму 5-9 млн \$США/год); с 2000 г. был сформирован холдинг по производству щелочных бенитонитов под руководством управляющей компании 000 «Компания «Бентонит» (г. Москва), организовавший добычу бентонита в Республике Хакасия, Курганской и Самарской областях, а также собственник бентонито- 
добывающего предприятия СП «АзРосПромИнвест» в Республике Азербайджан, поставляет в настоящее время до $80 \%$ российского потребления бентонита;

- сода, на фоне роста цены с 133 \$CША/т в 2013 г. до 150 \$США/т в 2016 г., уменьшила объемы импорта с 590 тыс. т в 2013 г. (23\% от потребления) до 90 тыс. т. в 2016 г. (4\%);

- молибденовый концентрат, импорт которого уменьшился (с 2,3 до 0,13 тыс. т/год) после резкого увеличения цены на него с 7500 \$CША/т (2003 г.) до 33340 \$CША/т (2005 г.).

Наоборот, под влиянием все того же ценового фактора произошло увеличение импортозависимости для:

- иинкового кониентрата (см. выше в анализе изменений объемов импорта);

- полевого шпата - в результате появления в России новой отрасли производства керамогранита увеличил свой уровень импортозависимости; потребление этого сырья увеличилась с 260 тыс. т в 2002 г. до 1255 тыс. т в 2015 г.; при этом объемы импорта выросли с 3 тыс. т/год (1 \% от потребления) до 550 тыс. т/год (45\%); росту импорта способствовали относительно низкие цены на импортируемый полевой шпат с Украины.

\section{Неценовые факторы изменений импортозависимости дефицитных видов минеральных товарных продуктов}

Конечно, не только ценовый фактор способствовал уменьшению или увеличению импортозависимости отдельных минеральных товаров. Это возможно в результате изменений объемов национального производства и потребления минерального сырья (как увеличения, так и уменьшения), наличия альтернативных материалов, которые могут заменять дефицитное сырье, установления надежных партнерских связей с зарубежными поставщиками (в т. ч. и новые), транспортной логистики (расположения производителей и потребителей сырья в противоположных частях страны) и других причин. На основе преобладания неценовых факторов:

- Уменьшили импортозависимость:

$\checkmark$ феррололибден, цены на который, как и на молибденовый концентрат, выросли с 6500 \$США/т в 2003 г. до 44000 \$CША/т в 2005 г.; благодаря росту конъюнктуры ферромолибдена были построены новые ферросплавные заводы в г. Сорск (Республике Хакассия) и в п. Жерекен (Забайкальский край), специализированные на выпуск ферромолибдена; доля импорта этого продукта упала с 77 \% в 2007 г. до 5 \% в 2016 г.;

$\checkmark$ ферроларганеи, для которого имеется тенденция его залещения в качестве легирующего компонента в металлургии более дешевым силикомарганиел (см. выше в анализе изменений объемов импорта); $\checkmark$ барит, чье потребление в качестве утяжеления буровых растворов выросло с 70 тыс. т в 1996 г. до 420 тыс. т в 2016 г., стимулировал расширение российской добычи на новых предприятиях - А0 «Барит» в Республике Хакассия и $\mathrm{AO}$ «Хайлинский ГОК» в республике Коми; доля импорта упала с 84 \% в 1998 г. до 7 \% в 2007 г. и опять начала расти (до 10-35\% в 2007-2016 гг.) именно в результате опережающего роста потребления.

- Увеличили импортозависимость:

$\checkmark$ олово рафинированное - в результате коллапса оловянной отрасли, приведшей к закрытию большинства добывающих производств и единственного в России предприятия, перерабатывающего оловянное сырье $\mathrm{OAO}$ «Новосибирский оловянный комбинат»; если в начале 1990-х гг. производство олова составляла до 19,8 тыс. т в год (8-9-е место в миpe), то к 2000 г. снижено до 7 тыс. т, а в 2014 г. его выпуск прекращен [24];

$\checkmark$ вольфраловый кониентрат, который российские потребители в европейской части страны вынуждены приобретать по импорту - до 1,7 тыс. т в 2015 г. (38 \% от потребления), когда добывающие предприятия на Дальнем Востоке большую часть вольфрамовых концентратов экспортируют в страны Азии;

$\checkmark$ борная кислота, импорт которой вырос с 6 тыс. т в 2013 г. (31\% от потребления) до 16 тыс. т в 2016 г. (67\% ), см. выше в анализе изменений объемов импорта;

$\checkmark$ хлористый натрий, увеличивший импорт с 660 тыс. т в 2001 г. (19\% от потребления) до 1800 тыс. т в 2016 г. (37 \% ) (см. выше в анализе изменений объемов импорта).

\section{Выводы}

1. За период 1996-2016 гг. выросли мировые цены на следующие импортозависимые минеральные продукты: цинковый концентрат, барит, графит, олово рафинированное, хлорид натрия (каменная соль), бентонит, сода, цирконовый концентрат, глинозем, плавиковый шпат, хромовый концентрат, полевой шпат, диоксид титана (титановый пигмент), бокситы, каолин и огнеупорные глины. Мировые цены снизились на рутиловый концентрат и борную кислоту.

2. Выгодность импортных поставок товарных минеральных продуктов с ценами ниже мировых очевидна, но только при условии стабильности поставок. Но при этом вероятно быстрое прекращение импортных поставок. Поэтому определенную тревогу вызывает группа полной импортозависимости с ценами ниже мировых - марганцевые руды, марганец металлический, плавиковый шпат и феррониобий, поставки которых могут быть прекращены по неэкономическим (политическим) причинам. Необходимо создание национальных добываю- 
щих производств, хотя бы частично закрывающих дефицит этих товаров.

3. Ценовый фактор действует, стимулируя при высоких мировых ценах снижение импортозависимости бокситов, бентонита, соды и молибденового концентрата, и увеличение импортозависимости при снижении мировых цен для цинкового концентрата и полевого шпата.

4. Выделяется группа товарных видов минерального сырья с импортными ценами на уровне

\section{СПИСОК ЛИТЕРАТУРЫ}

1. Назарова 3.М. Анализ отраслевой организации рынков минерального сырья для целей ценообразования / Известия высших учебных заведений. Геология и разведка. - 2003. - № 3. - С. 78-83.

2. Hunter D., Alperowicz N. HF feels pressure from rising fluorspar prices // Chemical Week. - 2003. - V. 165. - Iss. 43. - P. 42-44.

3. Nangolo C., Musingwini C. Empirical correlation of mineral commodity prices with exchange-traded mining stock prices // Journal of the Southern African Institute of Mining and Metallurgy. - 2011. - V. 111. - Iss. 7. - Pp. 459-468.

4. Бурчаков В.А., Толмачёв А.И. Анализ факторов, влияющих на конъюнктуру рынка минерального сырья // Горный информационно-аналитический бюллетень. - 2010. - № 7. - С. 41-45.

5. An empirical approach to determine specific weights of driving factors for the price of commodities-A contribution to the measurement of the economic scarcity of minerals and metals / B. Gleich, B. Achzet, H. Mayer, A. Rathgeber // Resources Policy. - 2013. - V. 38. - Iss. 3. - P. 350-362. DOI: 10.1016/j.resourpol.2013.03.011.

6. Mineral resources: Geological scarcity, market price trends, and future generations / M.L.C.M. Henckens, E.C. van Ierland, P.P.J. Driessen, E. Worrell // Resources Policy. - 2016. V. 49. - P. 102-111. DOI: 10.1016/j.resourpol.2016.04.012.

7. Shadow prices and production inefficiency of mineral resources / T. Tamaki, K.J. Shin, H. Nakamura, H. Fujii, S. Managi // Economic Analysis and Policy. - 2018. - V. 57. - P. 111-121. DOI: 10.1016/j.eap.2017.03.005.

8. Стратегия развития горного дела как основы экономики и национальной безопасности страны / В.Ж. Аренс, А.С. Астахов, Е.А. Козловский, М.И. Щадов // Горный информационно-аналитический бюллетень. - 1998. - № 3. - С. 63-69.

9. Хатьков В.Ю., Боярко Г.Ю. Регулирование импорта дефицитного для России минерального сырья // Горный журнал. 2005. - № 9-10. - С. 53-56.

10. Семененко Ю. Российский ниобий. Первая ласточка из Сибири // Природо-ресурсные ведомости, 31 августа 2001 года.

11. Боярко Г.Ю., Хатьков В.Ю. Добыча ниобия в России // Известия Томского политехнического университета. - 2004. T. 307. - № 1. - C. 149-153.

12. 35 Minerals Absolutely Critical to U.S. National Security. Draft list released by feds on Feb 16th, 2018. URL: http://www.visualcapitalist.com/35-minerals-critical-security-u-s// (дата обращения: 10.12 .2018$)$. мировых $( \pm 5 \%)$, изменения объемов импорта которых регулируется неценовыми факторами - олово рафинированное, ферровольфрам, бура, силикомарганец, ферромарганец, графит и ферромолибден. В критическую группу с преобладанием неценовых факторов входят также: вольфрамовый концентрат, борная кислота, хлорид натрия (каменная соль), хромовый концентрат, феррохром, диоксид титана (титановый пигмент).

13. Малявина А.В. Теоретические аспекты анализа ресурсной импортозависимости экономики // Экономика. Предпринимательство. Окружающая среда. - 2015. - Т. 4. - № 64. - С. 20-24.

14. Березинская 0., Ведев А. Зависимость российской экономики от импорта // Экономическое развитие России. - 2017. T. 24. - № 4. - C. 19-25.

15. Глушич Н.Г., Лядова Е.В., Удалова Н.А. Основные противоречия реализации политики импортозамещения в экономике России // Журнал экономической теории. - 2017. - № 1. - С. 22-31.

16. Rohr M., Fernández J.I., López V.P. Funciones de demanda del comercio exterior: Aproximación a una relación a largo plazo para la Federación de Rusia // Revista de Economia Mundial. 2015. - № 39. - Article number A009. - P. 143-178.

17. Ermolaev S.A., Cherednichenko L.G., Dubovik M.V. Import substitution in the context of theory and practice of industrial policy // International Journal of Applied Business and Economic Research. - 2016. - V. 14. - № 15. - P. 11123-11135.

18. Hotelling H. The Economics of Exhaustible Resources // Bulletin of Mathematical Biology. - 1991. - V. 53. - № 1-2. P. 281-312. DOI: $10.1007 / \mathrm{BF} 02464433$.

19. Государственные доклады «0 состоянии и использовании минерально-сырьевых ресурсов Российской Федерации». 2001-2015. - M.: MПР РФ, 2001-2015. URL: http://www.mnr. gov.ru/docs/gosudarstvennye doklady/o sostoyanii i ispolzovanii_mineralno_syrevykh_resursov_rossiyskoy_federatsii/ (дата обращения: 10.12 .2018$)$

20. Федеральная служба государственной статистики России. URL: http://www.gks.ru/wps/wcm/connect/rosstat_main/rosstat/ru/statistics/enterprise/industrial/\# (дата обращения: 10.12.2018).

21. Федеральная таможенная служба России. URL: http://stat. customs.ru/analytics/ (дата обращения: 06.06.2018).

22. U.S. Geological Survey. Mineral commodity summaries 1996-2017. - Pittsburgh, PA (USA): USGS, 1997-2017. URL: https://minerals.usgs.gov/minerals/pubs/mcs/ (дата обращения: 10.12.2018).

23. Хатьков В.Ю., Боярко Г.Ю. Мировые и российские встречные импортно-экспортные потоки минерального сырья // Известия Томского политехнического университета. Инжиниринг георесурсов. - 2018. - Т. 329. - № 3. - С. 145-167.

24. Боярко Г.Ю., Хатьков В.Ю. Мировой рынок олова и современное состояние оловянной промышленности России // Цветные металлы. - 2018. - № 1. - C. 47-55. DOI: 10.17580/tsm.2018.01.06.

Поступила 22.12.2018 2.

\section{Информация об авторах}

Боярко Г.Ю., доктор экономических наук, кандидат геолого-минералогических наук, профессор отделения нефтегазового дела Инженерной школы природных ресурсов Национального исследовательского Томского политехнического университета.

Хатьков В.Ю., начальник департамента 817 ПАО «Газпром»; соискатель Национального исследовательского Томского политехнического университета. 


\title{
PRICING FACTOR FOR IMPORT OF LIMITED MINERAL RAW MATERIALS
}

\author{
Grigory Yu. Boyarko', \\ gub@tpu.ru \\ Vitaly Yu. Khatkov ${ }^{2,1}$, \\ vitaliy@payler.com \\ 1 National Research Tomsk Polytechnic University, \\ 30, Lenin Avenue, Tomsk, 634050, Russia. \\ 2 Gazprom, \\ 2, Pobedy square, St. Petersburg, 196143, Russia.
}

\begin{abstract}
The relevance of the work is caused by the need to study the influence of a price factor on the commodity flows of Russian import-dependent mineral products.

The aim of this study is the investigation of changes in world prices for import-dependent mineral products, definition of types of import-dependent mineral raw materials, the volume and share of imports of which depend on the price factor.

Research methods: statistical, graphic, logical.

Results. During the period of 1996-2016, the world prices for the following import-dependent mineral products: zinc concentrate, barite, graphite, refined tin, sodium chloride (rock salt), bentonite, soda, zirconium concentrate, alumina, hydrofluoric spar, chromium concentrate, feldspar, titanium dioxide (titanium pigment), bauxite, kaolin and refractory clays, increased. World prices have decreased for rutile concentrate and boric acid. The profitability of imports of commodity mineral products with prices lower than the world ones is obvious, but only if their supply is stable. But at the same time, it is likely that import supplies will stop quickly. The group of total import dependence with prices lower than the world prices - manganese ore, manganese metal, hydrofluoric feldspar, and ferroniobium, which can be stopped for non-economic (political) reasons, is of some concern. It is necessary to create national extractive industries, at least partially closing the deficit of these goods. The price factor acts by stimulating, at high world prices, a decrease in the import dependence of bauxite, bentonite, soda and molybdenum concentrate, and an increase in import dependence with a decrease in world prices for zinc concentrate and feldspar. A group of commodity types of mineral raw materials with import prices at the level of the world ones, changes in the volume of imports of which are regulated by non-price factors - refined tin, ferrovolfram, borax, silicomanganese, ferromanganese, graphite and ferromolybdenum. The critical group with a predominance of non-price factors also includes import-dependent products: tungsten concentrate, boric acid, sodium chloride (rock salt), chromium concentrate, ferrochrome, titanium dioxide (titanium pigment).
\end{abstract}

\section{Key words:}

Mineral raw materials, imports, national consumption, price factor, import substitution.

\section{REFERENCES}

1. Nazarova Z.M. Analysis of industry organization of mineral raw materials markets for pricing. Bulletin of higher educational institutions. Geology and exploration, 2003, no. 3, pp. 78-83. In Rus.

2. Hunter D., Alperowicz N. HF feels pressure from rising fluorspar prices. Chemical Week, 2003, vol. 165, Iss. 43, pp. 42-44.

3. Nangolo C., Musingwini C. Empirical correlation of mineral commodity prices with exchange-traded mining stock prices. Journal of the Southern African Institute of Mining and Metallurgy, 2011, vol. 111, Iss. 7, pp. 459-468.

4. Burchakov V.A., Tolmachev A.I. Analysis of factors affecting the market of mineral raw materials. Bulletin mining information and analytical, 2010, no. 7, pp. 41-45. In Rus.

5. Gleich B., Achzet B., Mayer H., Rathgeber A. An empirical approach to determine specific weights of driving factors for the price of commodities-A contribution to the measurement of the economic scarcity of minerals and metals. Resources Policy, 2013, vol. 38, Iss. 3, pp. 350-362. DOI: $10.1016 /$ j.resourpol.2013.03.011.

6. Henckens M.L.C.M., Van Ierland E.C., Driessen P.P.J., Worrell E. Mineral resources: Geological scarcity, market price trends, and future generations. Resources Policy, 2016, vol. 49, pp. 102-111. DOI: 10.1016/j.resourpol.2016.04.012.

7. Tamaki T., Shin K.J., Nakamura H., Fujii H., Managi S. Shadow prices and production inefficiency of mineral resources. Econo- mic Analysis and Policy, 2018, vol. 57, pp. 111-121. D0I: 10.1016/j.eap.2017.03.005.

8. Arens V.Zh., Astahov A.S., Kozlovsky E.A., Shchadov M.I. Mining development strategy as the basis of the country economy and national security. Bulletin mining information and analytical, 1998, no. 3, pp. 63-69. In Rus.

9. Khatkov V.Yu., Boyarko G.Yu. Import regulation for mineral raw materials that are lacking in Russia. Gorny zhurnal, 2005, no. 9-10, pp. 53-56. In Rus.

10. Semenenko Yu. Rossiyskiy niobiy. Pervaya lastochka iz Sibiri [Russian niobium. The first swallow from Siberia]. Prirodo-resursnye vedomosti, 31 August 2001.

11. Boyarko G.Yu., Khatkov V.Yu. Niobium mining in Russia. Bulletin of the Tomsk Polytechnic University, 2004, vol. 307, no. 1, pp. 149-153. In Rus.

12. 35 Minerals Absolutely Critical to U.S. National Security. Draft list released by feds on Feb $16^{\text {th }}$, 2018. URL: http://www.visualcapitalist.com/35-minerals-critical-security-u-s/ (accessed 10 December 2018).

13. Malyavina A.V. Theoretical analysis of resource import dependence of the economics. Economy. Business. Environment, 2015, vol. 4, no. 64, pp. 20-24. In Rus.

14. Berezinskaya 0., Vedev A. Dependence of the Russian economy on imports. Russian economic development, 2017, vol. 24, no. 4, pp. 19-25. In Rus.

15. Glushich N.G., Lyadova E.V., Udalova N.A. The main contradictions in implementation of the policy of import substitution in the 
Russian economy. Journal of economic theory, 2017, no 1, pp. 22-31. In Rus.

16. Rohr M., Fernández J.I., López V.P. Funciones de demanda del comercio exterior: Aproximación a una relación a largo plazo para la Federación de Rusia [Import-export demand function: Approach to a long-run relationship for the Russian Federation]. Revista de Economia Mundial, 2015, no. 39, Article number A009, pp. 143-178. In Span.

17. Ermolaev S.A., Cherednichenko L.G., Dubovik M.V. Import substitution in the context of theory and practice of industrial policy. International Journal of Applied Business and Economic Research, 2016, vol. 14, no. 15, pp. 11123-11135.

18. Hotelling H. The Economics of Exhaustible Resources. Bulletin of Mathematical Biology, 1991, vol. 53, no. 1-2, pp. 281-312. DOI: $10.1007 / \mathrm{BF} 02464433$.

19. Gosudarstvenny doklad «O sostoyanii i ispolzovanii mineralno-syrevykh resursov Rossiyskoj Federatsii». 2001-2015 [State reports "On the state and use of mineral resources of the Russian Federation». 2001-2015]. Moscow, MPR RF, 2001-2015. Available at: http://www.mnr.gov.ru/docs/gosudarstvennye_doklady/0_sostoyanii_i_ispolzovanii_mineralno_syrevykh_resursov_rossiyskoy_federatsii/ (accessed 10 December 2018).
20. Federalnaya sluzhba gosudarstvennoy statistiki Rossii [Federal state statistics service of Russia]. Available at: http://www.gks.ru/wps/wcm/connect/rosstat_main/rosstat/ru/statistics/enterprise/industrial/\# (accessed 06 June 2018).

21. Federalnaya tamozhennaya sluzhba Rossii [Federal customs service of Russia]. Available at: http://stat.customs.ru/analytics/; https://ved-import.com/import/tnved/ (accessed 10 December 2018).

22. Mineral commodity summaries 1996-2017. U.S. Geological Survey. Pittsburgh, PA (USA). Available at: https://minerals.usgs.gov/minerals/pubs/mcs/ (accessed 10 December 2018).

23. Khatkov V.Yu., Boyarko G.Yu. World and Russian counter import/export flows of mineral products. Bulletin of the Tomsk $P_{0}$ lytechnic University. Geo Assets Engineering, 2018, vol. 329, no. 3, pp. 145-167. In Rus.

24. Boyarko G.Yu., Khatkov V.Yu. Global market of tin and modern state of tin industry in Russia. Tsvetnye metally, 2018, no. 1, pp. 47-55. In Rus. D0I: 10.17580/tsm.2018.01.06.

Received: 22 December 2018.

\section{Informationabout the authors}

Grigory Yu. Boyarko, Dr. Sc., Cand. Sc., professor National Research Tomsk Polytechnic University.

Vitaly Yu. Khatkov, head of Department, Gazprom; postgraduate, National Research Tomsk Polytechnic University. 